\title{
Polymorphonuclear proteolytic activity and milk composition change
}

\author{
Yves Le RouX*, François LAURENT, Fatima MoussaOuI \\ Laboratory of Animal Science, National Polytechnic Institute of Lorraine, ENSAIA-INRA, \\ 2, avenue de la Forêt de Haye, 54505 Vandœuvre-lès-Nancy Cedex, France
}

(Received 31 October 2002; accepted 21 March 2003)

\begin{abstract}
Relationships between Quarter Milk Cell Count (QMCC) and Tank Milk Cell Count (TMCC) with milk biochemical and technological parameters in milk and dairy products were investigated. All parameters measured were affected by the increase of TMCC and QMCC between 0 and 600000 cells $/ \mathrm{mL}$. The variable effect of lactation stage which is different for different authors, is discussed. The three mechanisms, measured during the inflammation of the udder, implicated in the modification of milk quality are described (a decrease in synthesis, a decrease in the milk barrier permeability and an increase in proteolytic activities). The direct effect of plasmin in caseinolysis is well known; the specific role of the increase of somatic cells (especially PMN) in the modification of milk quality is described. Several specific proteolytic activities of PMN are described and the impact of these activities on caseinolysis is evaluated. Two hypothetical mechanisms of caseinolysis by PMN are suggested and a synthetic scheme of the role of plasmin, bacteria and somatic cells in caseinolysis is discussed.
\end{abstract}

caseinolysis / mastitis / milk / PMN proteases / SCC

Table of contents

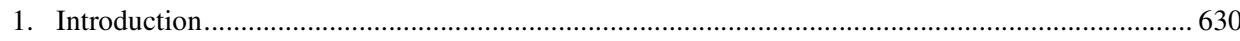

2. The relationship between SCC, milk composition and dairy products.............................................630

2.1. The relationship between SCC and milk composition in quarter milk .................................6 630

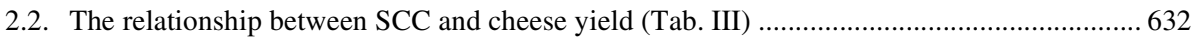

2.3. The relationship between SCC and pasteurized milk and UHT milk .....................................633

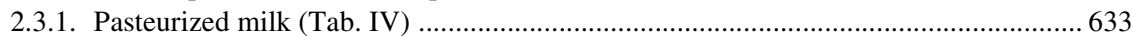

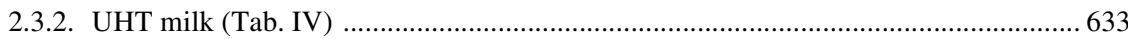

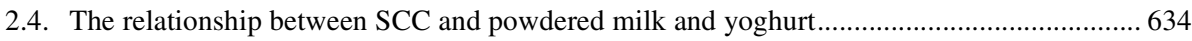

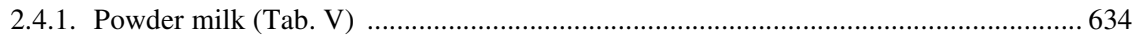

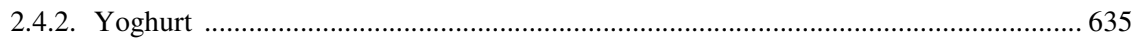

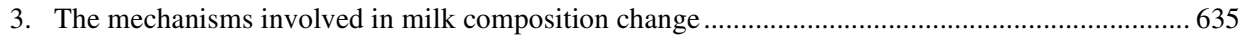

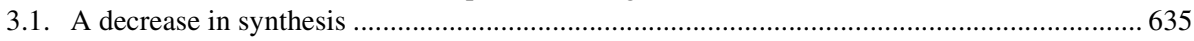

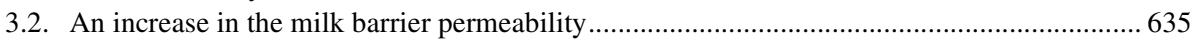

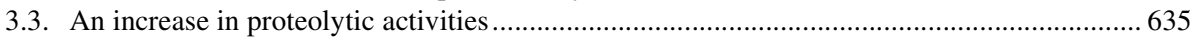

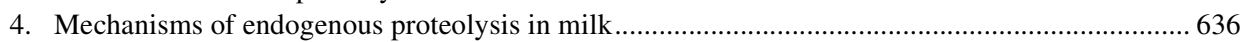

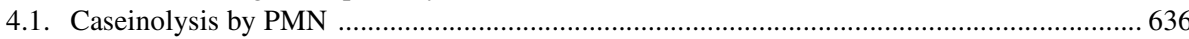

4.2. The relationships between the main events involved in milk composition change ................638 638

\footnotetext{
* Corresponding author: yves.leroux@ensaia.inpl-nancy.fr
} 
4.2.1. The relationship with the increase of the epithelial barrier permeability ....................638

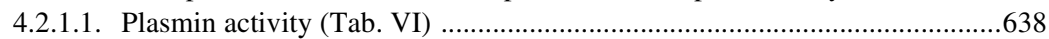

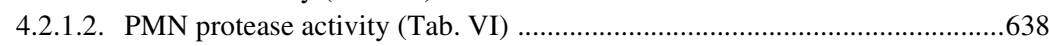

4.2.2. The relationship with the PMN stage of maturity ....................................................640

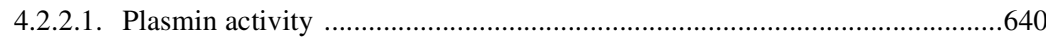

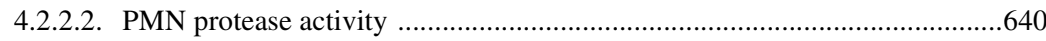

4.2.3 The relationship with the inflammatory process ...............................................641

4.2.4. The relationship with bacteria ......................................................................641

4.2.4.1. Bacterial capacity to promote plasminogen activation .............................641

4.2.4.2. Bacterial capacity to promote permeabilization of the epithelial barrier .....641

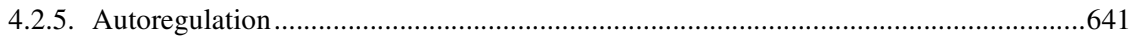

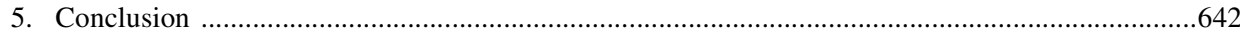

\section{INTRODUCTION}

The variation in the biochemical composition and technological properties of milk and dairy products has various origins: the animal's diet, genetic factors and cold storage of the milk. Although the effect of an increase in cell concentration on the health of the animal is known from a pathological point of view, the consequences on the biochemical composition and technological properties of milk and dairy products remain unclear. Little research has described the relationship between somatic cells and the biochemical quality of milk $[19,40,41]$ and dairy products $[1-3,7,15,34,43]$ for quarter or tank milk.

First, this review presents the current knowledge concerning the relationship between SCC and the biochemical quality of milk and dairy products; next, the mechanisms involved in the modification of the biochemical quality of milk are described and lastly, the roles of somatic cell proteases in this modification are discussed.

\section{THE RELATIONSHIP BETWEEN SCC, MILK COMPOSITION AND DAIRY PRODUCTS}

\subsection{The relationship between SCC and milk composition in quarter milk}

The single-quarter milk approach is the level of analysis in which the mechanisms involved in modifying the composition of milk may be described, whereas the tank milk level corresponds to the economic approach related to milk collection from dairy farms. Data obtained from pooling the milk of all four quarters are more difficult to interpret; from pooled milk, we cannot obtain an adequate description of the mechanisms involved in the increase in cell concentration influencing the biochemical quality of the milk, nor does it correspond to an economic approach.

In quarter milk (Tab. I), an increase of SCC causes modifications of the composition of milk. These modifications are in relation to the level of SCC and are linked to the germ present in the udder, particularly in cases of clinical mastitis [19, 47, 48]. The threshold of SCC for a normal milk is variable in function of the authors but more often than not over $10^{5}$ cells $/ \mathrm{mL}[19$, $41,69]$. The decrease of synthesis in mammary epithelial cells (indicated by a decrease in lactose content) and the proteolysis (indicated by an increase in proteose-peptone content and plasmin activity) are statistically significant for low SCC (Tab. I).

The SCC, which is a marker of the health of the udder, appears to be a good indicator of the biochemical composition of milk obtained from a single quarter. No threshold seems to exist between 0 and up to 600000 cells $/ \mathrm{mL}$.

In bulk milk (Tab. II), the relations between an increase in tank milk cell 
PMN proteolytic activity and milk composition change

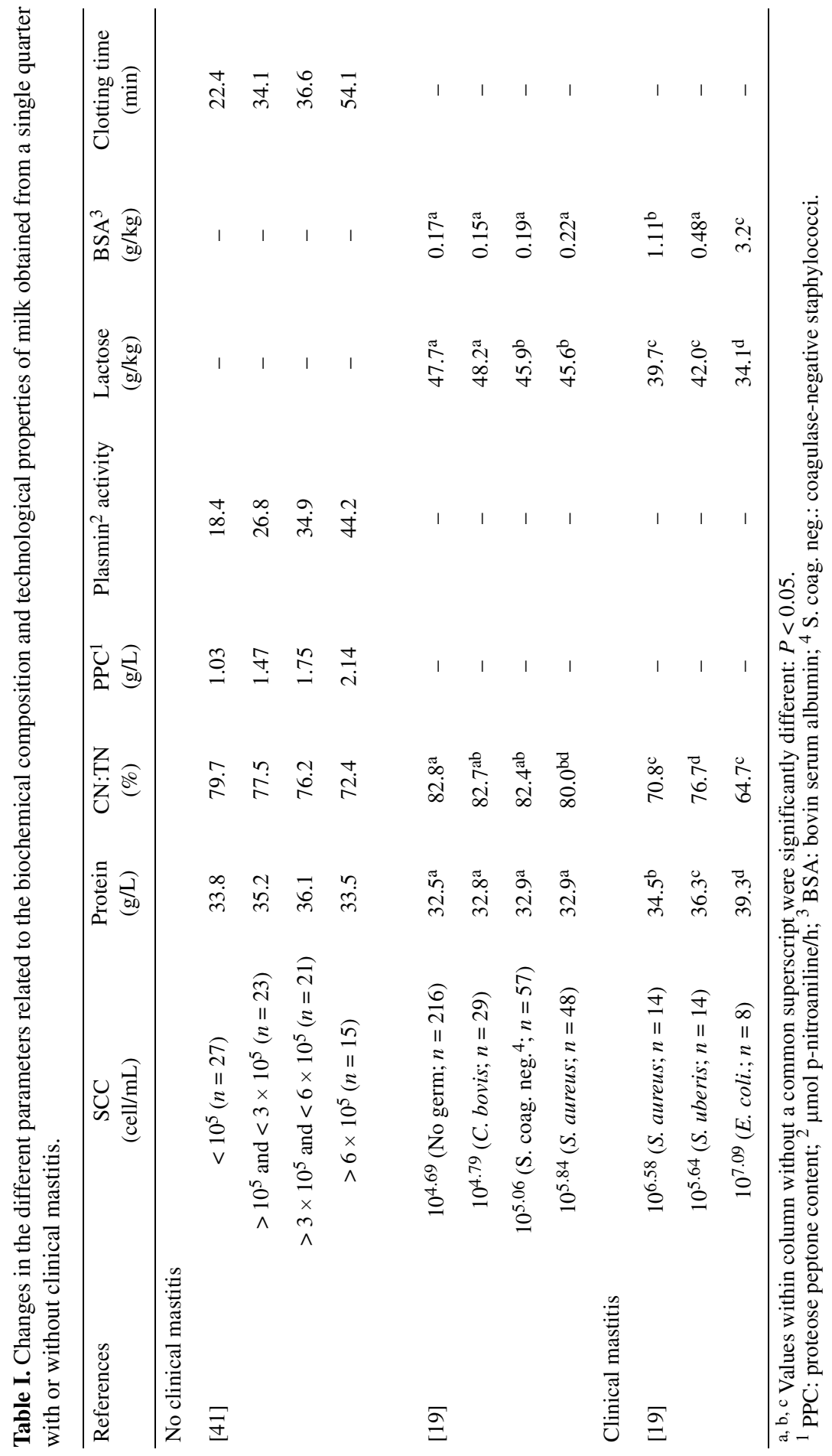


Table II. Changes in the different parameters related to the biochemical composition and technological properties of tank milk (early and late lactation stage) with somatic cell counts comprised between 0 and 600000 cells/mL (adapted from [40]).

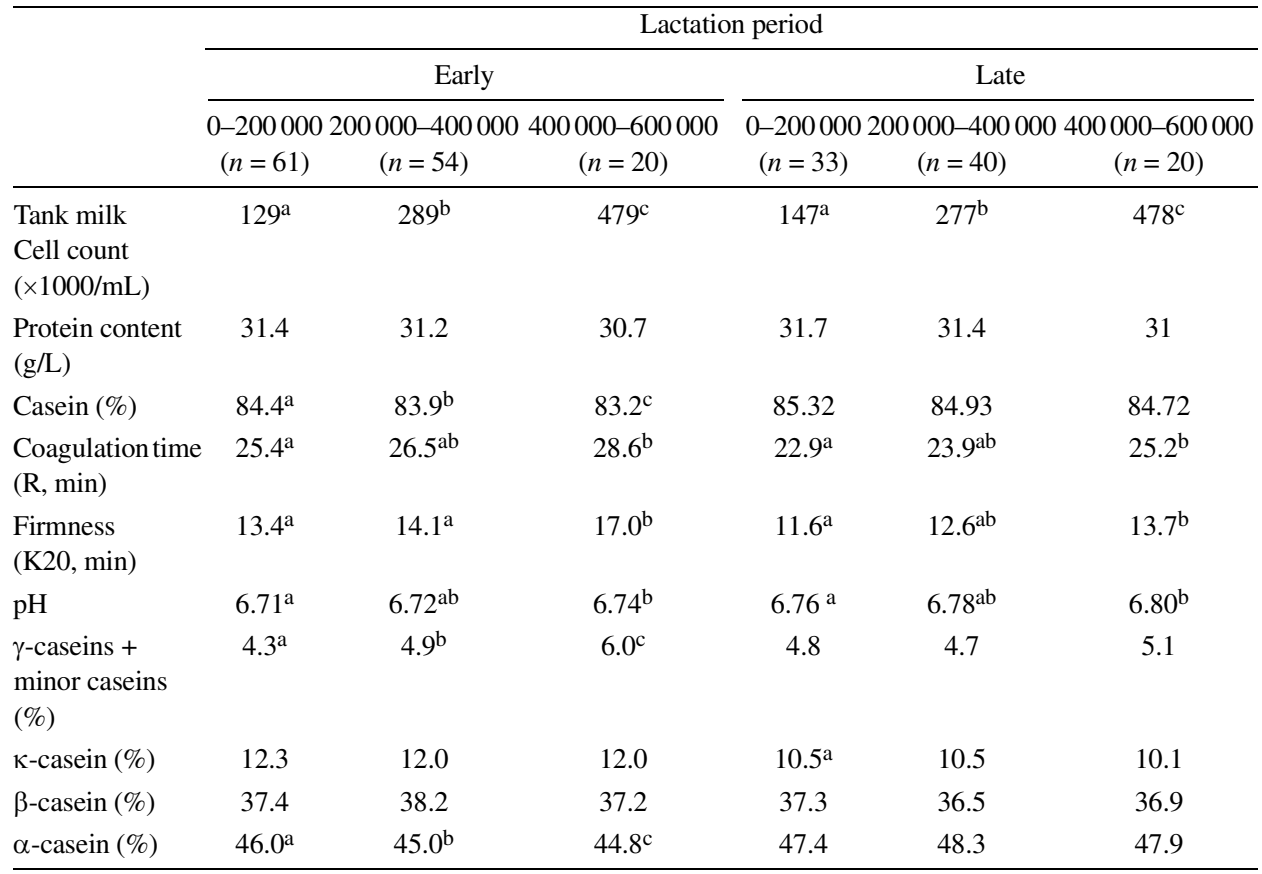

For each period of lactation (at the begining and end) ${ }^{\mathrm{a}, \mathrm{b}, \mathrm{c}}$ significantly different means at the threshold $P<0.05$.

count (TMCC) and milk composition are similar to those of quarter milk [40]. Nevertheless, it seems that TMCC below 200000 cells $/ \mathrm{mL}$ presents only minor risks of compositional change; with milk with 400-600 000 cells $/ \mathrm{mL}$, this risk is much greater particularly in interaction with the lactation stage $[1,40]$.

\subsection{The relationship between SCC and cheese yield (Tab. III)}

Whatever the technology, most authors showed a negative impact on cheese yield, casein loss into whey, slower rate of curd formation with high SCC milk $[1,7,15$, $34,66]$. In a recent review, Barbano [6] showed that the variations in milk SCC explain about half of the variation in milk plasmin and casein damage; other causes of variation (stage of lactation, health history and number of lactation) may interact with high SCC to produce a decrease in cheese yield efficiency. Recently, Cooney et al. [15] have suggested the direct role of the proteases (particularly cathepsin D) of the polymorphonuclear leukocytes on the ripening of Swiss-type cheese and on the high level of indigenous proteolysis in milk with high SCC and high PMN content. For Kelly et al. [33], it would be of great interest to link change in PMN concentration, and not just SCC, to milk quality or processing characteristics of milk, indeed PMN have different enzyme profiles than macrophages. For these authors, the possibility exists that PMN may act as a marker for certain functional properties of milk, which could be used by processors to screen bulk milks. 
Table III. Chemical composition of raw milk used for cheesemaking with high and low bulk milk cell counts.

\begin{tabular}{|c|c|c|c|c|c|c|c|c|c|c|c|c|}
\hline \multirow[b]{3}{*}{$n$} & \multicolumn{3}{|c|}{ Cheddar cheese [7] } & \multicolumn{4}{|c|}{$\begin{array}{c}\text { Cheddar cheese } \\
\text { [1] }\end{array}$} & \multirow{2}{*}{\multicolumn{2}{|c|}{$\begin{array}{c}\text { Cottage } \\
\text { cheese [34] }\end{array}$}} & \multicolumn{3}{|c|}{$\begin{array}{l}\text { Swiss-type } \\
\text { cheese [15] }\end{array}$} \\
\hline & & & & \multicolumn{4}{|c|}{$\begin{array}{l}\text { Early lactation Late lactation } \\
\text { milk milk }\end{array}$} & & & & & \\
\hline & 7 & 8 & 7 & 3 & 3 & 3 & 3 & - & - & 3 & 6 & 5 \\
\hline $\mathrm{SCC}\left(10^{3} / \mathrm{mL}\right)$ & 106 & $127-544$ & $556-1300$ & 121 & 252 & 687 & 1463 & 83 & 872 & 113 & 228 & 528 \\
\hline Fat $(\mathrm{g} / \mathrm{L})$ & 37.5 & 36.8 & 38.3 & 45.1 & 52.0 & 44.5 & 49.3 & 51.0 & 58.0 & 32.3 & 38.1 & 43.6 \\
\hline Casein $(\mathrm{g} / \mathrm{L})$ & 25.4 & 25.2 & 25.6 & 23.4 & 27.1 & 22.5 & 24.0 & 24.6 & 25.8 & - & - & - \\
\hline$\%$ Casein $(\%)$ & 81.9 & 79.9 & 79.9 & 80.0 & 77.0 & 77.0 & 75.0 & 81.6 & 79.6 & $72.3^{1}$ & $73.7^{1}$ & $68.7^{1}$ \\
\hline $\begin{array}{l}\text { Milk protease } \\
\text { activity }^{2}\end{array}$ & 14.5 & 30.3 & 36.3 & 22.2 & 41.3 & 35.4 & 65.7 & - & - & 0.15 & 0.19 & 0.22 \\
\hline $\begin{array}{l}\text { Cheese protein } \\
\text { recovery }(\%)\end{array}$ & 74.81 & 73.34 & 73.32 & 78.7 & 78.3 & 77.5 & 74.4 & 76.4 & 73.8 & - & - & - \\
\hline $\begin{array}{l}\text { Adjusted yield } \\
\text { efficiency }\end{array}$ & 99.4 & 98.3 & 98.0 & - & - & - & - & 101.5 & 97.2 & - & - & - \\
\hline $\begin{array}{l}\text { Cheese } \\
\text { grading }(/ 100)\end{array}$ & - & - & - & 91.7 & 88.7 & 91.3 & 87.3 & - & - & - & - & - \\
\hline
\end{tabular}

$\overline{{ }^{1} \text { Calculated from milk protein - milk non casein N. }{ }^{2} \text { Measured with differents methods: degradation of }}$ casein after incubation at $37{ }^{\circ} \mathrm{C}$ [7]; plasmin activity with P-nitro aniline [1] and the AMC method [15].

Rogers and Mitchell [66] showed that the use of milk containing a TMCC > 500000 cells $/ \mathrm{mL}$ results in a cheddar cheese with higher moisture content and proteolysis breakdown products, increased rennet coagulating time (by $25 \%$ ) and increased losses of fines, fat and protein in the whey resulting in a decrease in cheese yield of $8.9 \%$.

\subsection{The relationship between SCC and pasteurized milk and UHT milk}

\subsubsection{Pasteurized milk (Tab. IV)}

Ma et al. [43] showed that raw milk quality is lower in high SCC milk than in low SCC milk and also adversely affects the quality of pasteurized milk and decreases its shelf-life. During post-pasteurization cold storage, the rates of free fatty acid increase and casein hydrolysis is significantly high. The organoleptic quality of low SCC milk remains high after 21 days of cold storage whereas significant sensory defects are measured between 14 and 21 days of cold storage in high SCC milk.

\subsubsection{UHT milk (Tab. IV)}

Auldist et al. [2] observed that upon storage at $20^{\circ} \mathrm{C}$, early lactation UHT milk gels far ahead that of late lactation milk; within each stage of lactation, high SCC UHT milk tends to gel first. In the same study, the age of gelation was not always related to the level of proteolysis and few differences in the organoleptic properties between UHT milk manufactured with high SCC milk and low SCC milk were observed. In agreement with these results, Kelly and Foley [32] showed an increase in the activity of the cell-associated plasminogen activator in high SCC milk. 
Table IV. Effect of somatic cell count on the quality of Pasteurized and UHT milk.

\begin{tabular}{|c|c|c|c|c|c|c|}
\hline Type of milk & Pasteu & milk & & & & \\
\hline & & & Early la & on milk & Late la & n milk \\
\hline$n$ & 8 & 8 & 3 & 3 & 3 & 3 \\
\hline $\operatorname{SCC}\left(10^{3} / \mathrm{mL}\right)$ & 45 & 849 & 121 & 252 & 687 & 1463 \\
\hline Free Fatty Acids $(\mathrm{mM})$ & 0.27 & 0.43 & 0.43 & 0.45 & 1.37 & 1.27 \\
\hline$\%$ Caseins & 82.3 & 80.7 & $91^{\mathrm{a}}$ & $91^{\mathrm{a}}$ & $89^{\mathrm{a}}$ & $89^{\mathrm{a}}$ \\
\hline Proteolysis index & $1.7^{\mathrm{b}}$ & $4.0^{\mathrm{b}}$ & $17^{\mathrm{c}}$ & $17^{c}$ & $19^{c}$ & $28^{\mathrm{c}}$ \\
\hline Sensory analysis & & & & & & \\
\hline Odor & $1.07^{\mathrm{d}}$ & $2.25^{\mathrm{d}}$ & Good & Good & Good & Good \\
\hline Taste & $1.05^{\mathrm{d}}$ & $2.50^{\mathrm{d}}$ & Good & Good & Good & Good \\
\hline Gelification (month) & - & - & 6 & 6 & $>9$ & $>9$ \\
\hline
\end{tabular}

Table V. Effect of somatic cell count on the quality of full cream milk powder (adapted from [3]).

\begin{tabular}{|c|c|c|c|c|}
\hline \multirow[b]{2}{*}{$\operatorname{SCC}\left(\times 10^{3} / \mathrm{mL}\right)$} & \multicolumn{2}{|c|}{ Early lactation milk } & \multicolumn{2}{|c|}{ Late lactation milk } \\
\hline & $121^{\mathrm{a}}$ & $687^{b}$ & $252^{\mathrm{a}}$ & $1463^{\mathrm{c}}$ \\
\hline$n$ & 3 & 3 & 3 & 3 \\
\hline \multicolumn{5}{|l|}{ Powder components } \\
\hline Fat $(\mathrm{g} / \mathrm{kg})$ & $263^{\mathrm{a}}$ & $262^{\mathrm{a}}$ & $269^{\mathrm{a}}$ & $269^{\mathrm{a}}$ \\
\hline Total protein $(\mathrm{g} / \mathrm{kg})$ & $262^{\mathrm{a}}$ & $266^{\mathrm{a}}$ & $295^{\mathrm{b}}$ & $307^{c}$ \\
\hline Apparent casein $(\mathrm{g} / \mathrm{kg})$ & $242^{\mathrm{a}}$ & $241^{\mathrm{a}}$ & $270^{\mathrm{b}}$ & $278^{\mathrm{b}}$ \\
\hline Non-protein N (g/kg) & $2.15^{\mathrm{a}}$ & $2.17^{\mathrm{a}}$ & $2.62^{\mathrm{b}}$ & $2.33^{\mathrm{ab}}$ \\
\hline Lactose (g/kg) & $400^{\mathrm{a}}$ & $357^{\mathrm{b}}$ & $46.2^{\mathrm{a}}$ & $347^{b}$ \\
\hline $\mathrm{Na}(\mathrm{g} / \mathrm{kg})$ & $3.13^{\mathrm{a}}$ & $3.83^{\mathrm{b}}$ & $3.79^{\mathrm{b}}$ & $6.09^{\mathrm{c}}$ \\
\hline $\begin{array}{l}\text { Heat-stability }\left(10^{3} \mathrm{~kg} / \mathrm{m} / \mathrm{s}\right) \\
\text { (viscosity after sterilization, } \mathrm{pH} 6.50 \text {, } \\
\text { reconstituted milk) }\end{array}$ & 20 & 30 & 20 & 100 \\
\hline \multicolumn{5}{|l|}{ Organoleptic quality } \\
\hline $\begin{array}{l}\text { Odor and flavor (immediately after } \\
\text { manufacturing) }\end{array}$ & Good & Good & Good & Good \\
\hline Odor and flavor (after 4 months of storage) & Acceptable & Acceptable & Acceptable & Inacceptable \\
\hline
\end{tabular}

a, b, c Values within rows without a common superscript were significantly different: $P<0.05$.

\subsection{The relationship between SCC and powdered milk and yoghurt}

\subsubsection{Powder milk (Tab. V)}

Auldist et al. [3] showed that full cream milk powder manufactured from late lacta- tion milk with an elevated bulk milk cell count can display an altered heat stability compared to powder made from a low bulk milk cell count or milk from early lactation. Neither the bulk milk cell count nor stage of lactation has any effect on the organoleptic properties of milk powder 
immediately after manufacturing, although an elevated bulk milk cell count during late lactation does affect the organoleptic properties of the powder during storage.

\subsubsection{Yoghurt}

For skim milk yoghurt manufactured from milk with variable SCC, very few studies are available. Rogers and Mitchell [66] showed two different conclusions in the same study. The first, showed that the organoleptic grade of the yoghurt, made with a tank milk cell count $<250000$ cells $/ \mathrm{mL}$, is superior to that manufactured from milk $>250000$ cells $/ \mathrm{mL}$; however, the data from the second try indicates that there is no significant relationship between milk somatic cell count and the organoleptic grade of the yoghurt.

\section{THE MECHANISMS INVOLVED IN MILK COMPOSITION CHANGE}

During the inflammatory process, three mechanisms are involved in milk composition change: a decrease in synthesis, an increase in the permeability of the milk barrier and an increase in the proteolytic activities in milk.

\subsection{A decrease in synthesis}

Only a few studies have dealt with the impairment of the epithelial cells capacity of synthesis during inflammatory episodes. The lactose content, which is implicated in the osmoregulation in the milk, is considered as an indicator of the epithelial cells capacity of synthesis $[70,78]$. The decrease in lactose content leads to a decrease in milk production [21] with an alteration or a destruction of the epithelial cells by the leukocytes and mainly PMN [73] or with the invasion of the epithelial cells by bacteria like Staphylococcus aureus [10, 72]. As a result, the capacity of the synthesis of the epithelial cells is weakened [52] or may be due to a reorientation of cell metabolism.
In a recent study, Silanikove et al. [71] showed that the fragment of $\beta-\mathrm{CN}$ (f1-18) resulting from proteolysis is involved in the decrease in milk secretion, which could be caused by the blocking of $\mathrm{K}^{+}$ducts on the apical side of the epithelial cells.

\subsection{An increase in the milk barrier permeability}

Macrophages are the main somatic cells in the milk compartment of a healthy udder. In the presence of a pathogen, these cells play a key role in the immune defense by recruiting PMN from the blood compartment [65]. Macrophages release cytokines mainly IL- 8 and TNF- $\alpha$ that involve diapedesis. During the inflammatory process, the sequence of events as neutrophils pass from the blood into milk implicates, when mammary quarters are infected by $S$. aureus, three mechanisms described by Nickerson and Pankey [52]: mainly, a projection of neutrophils through degenerated luminal cells is observed and then a passage as desquamed luminal cells and a penetration between intact cell epithelia are measured. These different modes of migration across luminal cells into milk implicate the formation of holes in the cytoplasm of the epithelial cells and the apoptotic PMN cause a necrosis of the epithelial tissues [75]. These phenomena lead to a transfer of components between the blood and milk (from the blood to the milk and from the milk to the blood). The concentrations of a large number of components change in both compartments, amongst them BSA with +10 to $+20 \%$ in bulk milk $[19,77]$, citrate with $-28 \%$ in milk, $\mathrm{K}^{+}$with $-15 \%$ in milk, $\mathrm{Na}^{+}$and $\mathrm{Cl}^{-}$with respectively an increase of $+100 \%$ and +20 to $100 \%$ [28].

\subsection{An increase in proteolytic activities}

In milk, the main proteinase involved in casein breakdown is plasmin [22, 23, 39, 45]. Plasmin and its inactive zymogen, plasminogen vary considerably due to the stage of lactation, breed, and the age of the cow and mastitis. The importance of 
this protease milk alkaline proteinase (plasmin) is well known and has been extensively reviewed and the presence of plasmin in milk affects many dairy foods. Plasmin contributes to primary proteolysis of caseins during the ripening of most cheeses particularly in varieties which are cooked at high temperatures [8, 9]. In UHT milk, plasmin seems implicated in gelation during storage [35]. Milk obtained from mastitic or high SCC quarter milk contains high concentrations of plasmin [41]. Within the plasmin system, activators and inhibitors control plasmin activity. The plasminogen activator activity in relation with SCC has been widely investigated $[4,25$, 81] and more recently Precetti et al. [59] demonstrated the presence of two serine proteinase inhibitors of the plasmin system in bovine milk; $\alpha 2$-antiplasmin and plasminogen activator inhibitor-1, found by Zavizion et al. [82] in bovine mammary epithelial cells.

In the blood, most of the studies concerned collagenase, elastase and cathepsin activities. During the inflammatory response, the activities of these proteases are significantly increased as reported for collagenase [60], elastase [5,60], cathepsin $\mathrm{G}$ only [5] and both cathepsins $\mathrm{C}$ and $\mathrm{G}$ [60]. The role of these proteases in the degradation of the extracellular matrix is well known [5, 54]. Many studies report a high SCC during mastitis with mainly PMN [31]. PMN massive recruitment explains the increase of milk SCC and therefore a part of the increase of proteolytic activity. Recently, an increase in collagenase activity was reported in milk by Raulo et al. [62]. In vitro studies reported a caseinolytic capacity on different types of caseins of some proteases recovered in PMN: collagenase, susceptible to hydrolysate $\beta$-casein [24], cathepsin D, susceptible to hydrolysate $\beta$-casein, $\alpha_{\mathrm{s} 1}$-casein, $\alpha_{\mathrm{s} 2}$-casein and k-casein [37, 46]; cathepsin G susceptible to hydrolysate $\beta$-casein, $\alpha_{\mathrm{s} 1}$-casein [18] or elastase susceptible to hydrolysate $\beta$-casein, $\alpha_{\mathrm{s} 1}$-casein $[16,17]$. Recently, some authors have studied the potential impact of cathe- psin D in different cheese products: quarg cheese [30], and rennet free UF-feta cheese [38]. Cathepsin D is a heat stable lysosomal aspartic proteinase with a low $\mathrm{pH}$ optimum correlated with SCC [29] and may play a role in the ripening of high-cooked cheese varieties [15] and more in cheese varieties where no rennet is added (rennet free UF-feta cheese).

\section{MECHANISMS OF ENDOGENOUS PROTEOLYSIS IN MILK}

\subsection{Caseinolysis by PMN}

The degranulation of PMN seems to be the principal origin of the proteolytic activities with mainly neutral proteases such as elastase, collagenase, cathepsin G, proteinase 3, etc. [31, 54]. After LPS infusion, the capacity of caseinolysis of PMN neutral proteases and acidic proteases has been shown by Moussaoui et al. [50]. PMN are reported to contain acidic proteases such as cathepsins B, C, D or L [54]. These proteases are not at their optimal $\mathrm{pH}$ after degranulation since they are in the environment (milk) with a pH tending to neutrality, suggesting that neutral proteases cannot degrade proteins in an extra-cellular way. It is noteworthy that PMN have an important capacity of phagocytosis in comparison with other cells from the immune system. On this basis, two hypothetical mechanisms can be presented (Fig. 1).

A first mechanism could be "contact proteolysis" and would include the activity of acidic proteases limited by a very low local $\mathrm{pH}$ in the external periphery of the PMN, which would permit to degrade caseins in the neutral $\mathrm{pH}$ of milk. Proteases such as cathepsins B, C, D and L would be released by PMN from vesicles with a low $\mathrm{pH}$ such as lysosomes. The resulting casein fragments would be either released in milk or internalized by PMN.

A second mechanism could be "proteolysis by internalization": the ingestion of quantities of granules in vesicles of endocytosis (casein micelles, fat globules) by milk 

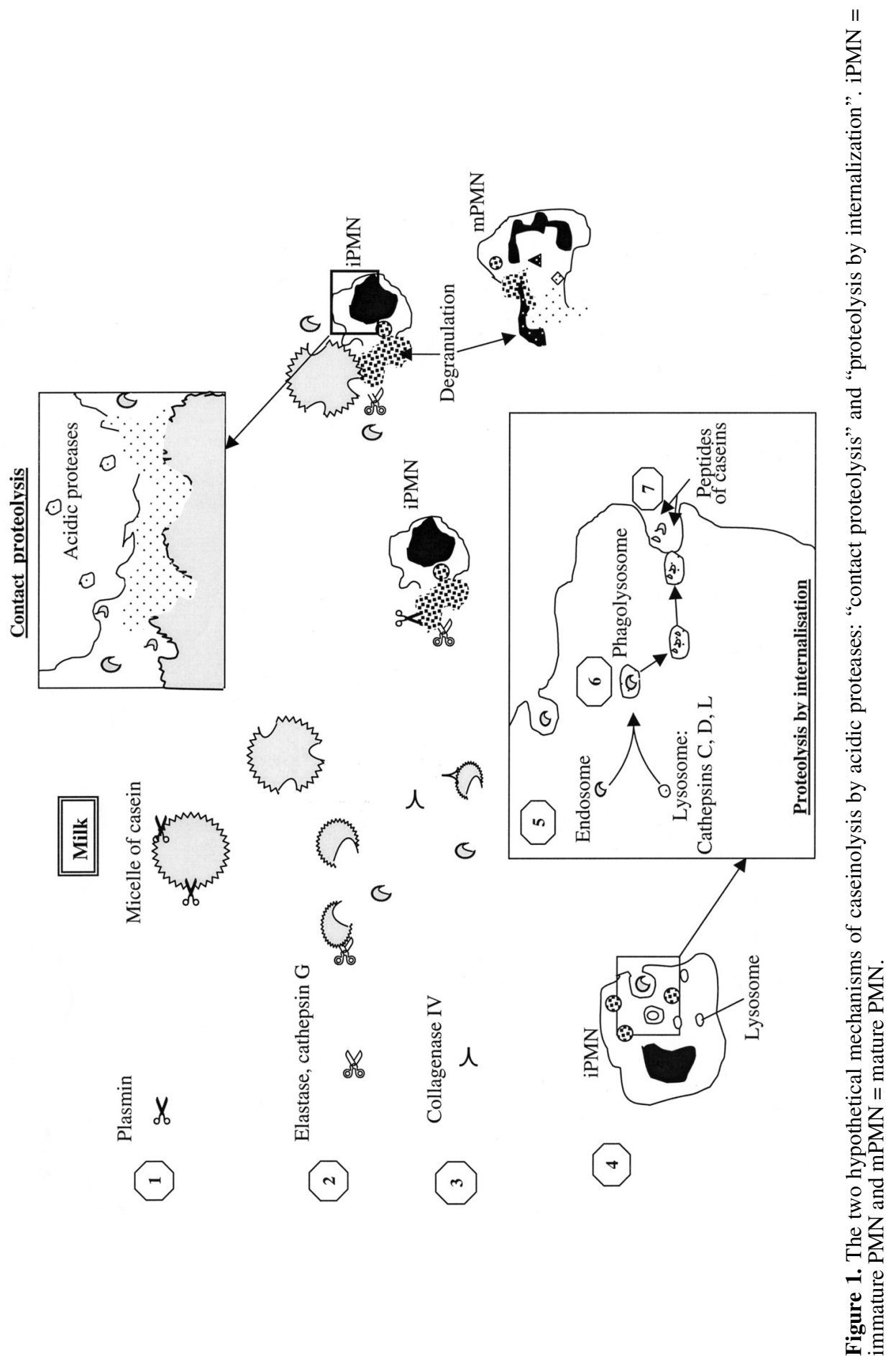
PMN has been largely demonstrated [55, $64,67]$. These vesicles would fusion with lysosomes, the acidic $\mathrm{pH}$ of the resulting phagosome would permit an optimal function of acidic proteases. The resulting degradation products would be partly or completely released in milk.

\subsection{The relationships between the main events involved in milk composition change (Fig. 2)}

\subsubsection{The relationship with the increase of the epithelial barrier permeability}

Plasmin and PMN proteases are both involved in the impairment of the milk barrier permeability through the degradation of the extracellular matrix. Plasmin, elastase and cathepsin G degrade glycoproteins such as fibronectin, thrombospondin and the Willerbrand factor [11]. PMN proteases degrade other proteins of the extracellular matrix such as collagen, gelatins, laminin, etc. [54].

\subsubsection{Plasmin activity (Tab. VI)}

The influx of a large number of blood components in milk has a positive effect on plasmin activity, first by the increase of the plasminogen concentration [68]. The epithelial barrier permeability could be responsible for an increase in plasminogen activator concentrations in milk (both tissular or t-PA and urokinase or the u-PA type) since these components are present in very high levels in the blood because of their involvement in blood clot dissolution [20]. Moreover, PMN synthesize plasminogen activators, mainly t-PA $[49,57]$. Other components with a main action other than plasminogen activation do have an effect on plasminogen conversion into plasmin. The epidermal growth factor (EGF) increases u-PA activity 10-fold [20]. The insulin-like growth factor I (IGF-I) whose concentration increases from 82 to
$150 \%$ during mastitis has been reported to have a stimulating effect on u-PA synthesis [56]. Prostaglandin E2 (PGE2) has a stimulating effect on u-PA and t-PA [9], concomitantly PGE2 concentration increases during mastitis [80]. Serine proteases stimulate the action of plasminogen activators which is as important as the increase of plasmin activity $(+570 \%$, [50]), cathepsin $\mathrm{G}$ from milk PMN $(+542 \%$, [60]) and elastase activities (+164\%, [60]). In addition, plasmin activates Collagenase IV by cleaving its zymogen [54].

The influx of blood components in milk could have a negative effect on plasmin activity by the increase of the concentration of plasminogen activators inhibitor. Retinoic acid (Vitamin A) has an increased concentration during mastitis [51] and therefore has an inhibitory effect on both u-PA and t-PA [20]. Glucocorticoids inhibit u-PA action and less markedly that of t-PA [20]. BSA, whose level is increased by $1427 \%$ during mastitis [23] has an inhibitory effect (25 to $65 \%$ inhibition) on both plasmin and plasminogen activities [58]. The same effects were observed for $\beta$-lactoglobulin and $\alpha$-lactalbumin by the same authors. $\alpha 1$-antitrypsin $(\alpha 1-\mathrm{AT})$ and $\alpha 2$-macroglobulin $(\alpha 2-\mathrm{Mg})$ have some increasing concentrations during mastitis [44, 51] and have, in addition, an inhibitory effect on u-PA and t-PA. The increase of $\alpha 1-\mathrm{AT}$ concentration is comprised between 2500 and $5700 \%$ in cases of $10 \mu \mathrm{g}$ LPS infusion [62].

\subsubsection{PMN protease activity (Tab. VI)}

The influx of blood components in milk involves both the inhibitory and activatory effects on PMN protease activities. The increase in the epithelial barrier permeability involves an increase in $\mathrm{Cl}^{-}$concentration in milk: e.g. $+79 \%$ in cases of experimental mastitis involving lipopolysaccharides (LPS) from E. coli [27]. Cathepsin $\mathrm{C}$ activity is reported to be increased by $\mathrm{Cl}^{-}[14]$. 
PMN proteolytic activity and milk composition change

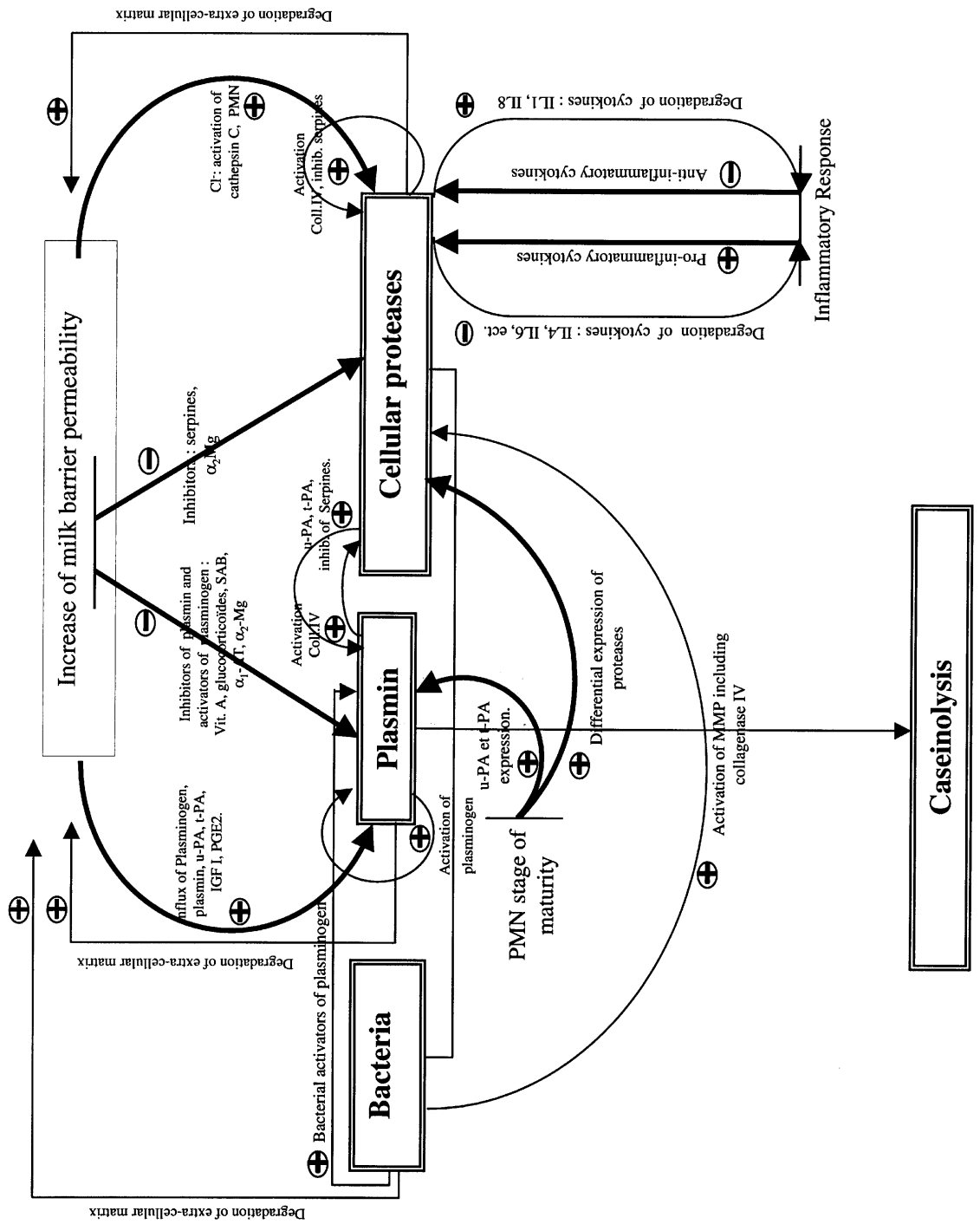

Z

$\stackrel{\dot{7}}{\Xi}$

$\ddot{z}$

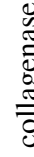

$\geq$

¿

当

.$\Xi$

$\frac{n}{n}$

$\frac{7}{2}$

שู

.

$\frac{0}{2}$

.

过

$\stackrel{\Xi}{ \pm}=$

웡.

竞

ڤ

.气ํㅡㄹ

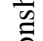

离

ㄱ

흘 
Table VI. Components with an activatory or inhibitory effect on plasmin (u-PA or t-PA) or on PMN proteases, variation of their concentrations during mastitis.

\begin{tabular}{|c|c|c|c|}
\hline Component & $\begin{array}{l}\text { Activation } \\
\text { or inhibition }\end{array}$ & Variation in milk with a high SCC & References \\
\hline \multicolumn{4}{|l|}{ Effect on plasmin } \\
\hline IGF I & $\oplus \mathrm{u}-\mathrm{PA}$ & +82 to $150 \%$ (quarter milk, $500 \mu \mathrm{g}$ LPS) & [13] \\
\hline \multirow[t]{4}{*}{ Serine Proteases } & $\oplus \mathrm{u}-\mathrm{PA}$ and $\mathrm{t}-\mathrm{PA}$ & $+570 \%$ for plasmin (quarter milk, $10 \mu \mathrm{g}$ LPS) & [50] \\
\hline & & $+19 \%$ for plasmin (bulk milk, subclinical mastitis) & [77] \\
\hline & & $\begin{array}{l}+542 \% \text { for cathepsins (G included, PMN quarter } \\
\text { milk, } 10 \mu \mathrm{g} \text { LPS) }\end{array}$ & [60] \\
\hline & & $\begin{array}{l}+164 \% \text { for elastase (PMN from quarter milk, } \\
10 \mu \mathrm{g} \text { LPS) }\end{array}$ & [60] \\
\hline $\mathrm{PGE}_{2}$ & $\oplus \mathrm{u}-\mathrm{PA}$ and $\mathrm{t}-\mathrm{PA}$ & NQ & [79] \\
\hline Vitamin A & $\ominus \mathrm{u}-\mathrm{PA}$ and $\mathrm{t}-\mathrm{PA}$ & NQ & [51] \\
\hline Glucocorticoids & $\ominus$ uPA and t-PA & +108\% (quarter milk, $500 \mu \mathrm{g}$ LPS) & [23] \\
\hline BSA & $\begin{array}{l}\ominus \text { plasmin and } \\
\text { plasminogen }\end{array}$ & $+1427 \%$ (quarter milk, $500 \mu \mathrm{g}$ LPS) & \\
\hline$\alpha_{1}$-AT & $\ominus \mathrm{u}-\mathrm{PA}$ and $\mathrm{t}-\mathrm{PA}$ & +2500 to $5700 \%$ (quarter milk, $10 \mu \mathrm{g}$ LPS) & {$[62]$} \\
\hline$\alpha_{2}-\mathrm{Mg}$ & $\ominus \mathrm{u}-\mathrm{PA}$ and $\mathrm{t}-\mathrm{PA}$ & NQ & $\begin{array}{l}{[44]} \\
{[51]}\end{array}$ \\
\hline \multicolumn{4}{|l|}{$\begin{array}{l}\text { Effect on PMN } \\
\text { proteases }\end{array}$} \\
\hline$\alpha_{1}$-AT & $\ominus$ elastase & +2500 to $5700 \%$ (quarter milk, $10 \mu \mathrm{g}$ de LPS) & {$[62]$} \\
\hline $\mathrm{Cl}^{-}$ & $\oplus$ cathepsin $\mathrm{C}$ & $+79 \%$ (quarter milk, $100 \mu \mathrm{g}$ de LPS) & [27] \\
\hline
\end{tabular}

u-PA = urokinase plasmin activator; $\mathrm{t}-\mathrm{PA}$ tissular plasmin activator; $\alpha_{1}-\mathrm{AT}=\alpha_{1}$-antitrypsin; $\mathrm{NQ}=$ non quantified; $\alpha_{2}-\mathrm{Mg}=\alpha_{2}$-macroglobulin; PGE2 = prostaglandin $\mathrm{E}_{2} ; \ominus=$ inhibition; $\oplus=$ activation.

The influx of $\alpha 1-\mathrm{AT}$ in milk during the inflammatory process [62] is involved in elastase inhibition [63] and that of cathep$\sin \mathrm{G}[5] . \alpha 2-\mathrm{Mg}$ is an inhibitor of the four classes of proteases [54] and its concentration in milk increases during mastitis [44, 61].

\subsubsection{The relationship with the PMN stage of maturity}

\subsubsection{Plasmin activity}

PMN express different types of proteases depending on their stage of matu- rity. These cells have the capacity of promoting plasminogen activity such as u-PA and less markedly t-PA [49]. In addition, the level of expression of plasminogen activators by PMN is intimately linked to the cell stage of maturity (Moussaoui et al., personnal communication).

\subsubsection{PMN protease activity}

Verdi and Barbano [79] showed that the proteolytic activity at $\mathrm{pH} 6.6$ was significantly higher for the somatic cell isolated from milk than for leucocytes isolated from the blood of healthy cows, this increase may 
be caused by a higher proportion of activated cells in somatic cells isolated from milk produced by cows with mastitis than in the leucocytes isolated from the blood of healthy cows. The PMN stage of maturity is linked to a differential expression of proteases located in different granules [12]. Serine proteases (e.g. elastase, cathepsin G) are expressed in azurophilic granules (or primary granules) at very early stages of maturity such as promyelocytes until metamyelocytes; such proteases are expressed at a low level in mature PMN [74]. Metalloproteases such as collagenases are expressed in gelatinase granules (or tertiary granules) at later stages of maturity such as metamyelocytes and band cells [12, 54]. Acidic proteases such as cathepsins B, C, D, $\mathrm{H}$ and $\mathrm{L}$ are located in lysosomes with an acidic environment [76] and are expressed by both primary and tertiary granules mainly for cathepsins B and D [31].

\subsubsection{The relationship with the inflammatory process}

The order of expression of the main PMN proteases cited below would be elastase, cathepsins $\mathrm{C}$ and $\mathrm{G}$, and collagenase IV [54, 74, 76]. PMN proteolytic activities are regulated by mediators of inflammation like cytokines. Pro-inflammatory cytokines promote the activity of such proteases at a transcriptionnal level, which is the case of IL-1 and IL-8 for collagenase IV [53], IL-6, IL-2 and TNF- $\alpha$ for serine proteases such as elastase and cathepsin $\mathrm{G}[5]$.

In order to limit the inflammatory response, anti-inflammatory cytokines such as IL-4, IFN- $\beta$, IL-6 and IL-10 inhibit the expression of collagenase IV [53]; other cytokines such as IL- $1 \beta$, TNF- $\alpha$, TGF- $\beta$ and IL-8 inhibit serine proteases [5]. These proteases have a key role in immunomodulation by cleaving IL- 1 and IL- 8 by collagenase IV, IL-6, IL-2 and TNF- $\alpha$ by serine proteases such as elastase, cathepsin $\mathrm{G}$ and proteinase $3[5,53]$.

\subsubsection{The relationship with bacteria}

\subsubsection{Bacterial capacity to promote plasminogen activation}

The production of $\mathrm{u}-\mathrm{PA}$ has been found to be enhanced in bovine mammary epithelial cells infected by $S$. aureus [83] as well as in human monocytes infected by Borrelia burgdorferi [36]. Two groups of bacterial plasmin activators have been reported: streptokinase (SK) and staphylokinase (SAK). Both components bind plasminogen and plasmin leading to a conformational change of plasmin or plasminogen. The complexes acquire a remarkable efficiency to activate plasminogen [36]. A protein from Streptococcus uberis has been reported to activate bovine plasminogen [42]. Many bacteria express a receptor plasminogen (PlgRs) on their surface, which has been reported for $S$. aureus, E. coli, Salmonella typhimurium. The role of PlgRs is the immobilization of Plg, which enhances Plg activation [36].

\subsubsection{Bacterial capacity to promote permeabilization of the epithelial barrier}

Bacteria bound to plasmin have been shown to degrade the extracellular matrix and promote the permeabilization of the mammary epithelium. This complex activates collagenase IV and more widely metalloproteinases by cleaving the zymogen [36].

\subsubsection{Autoregulation}

Plasmin regulates its own activity as long as it is involved with urokinase in plasminogen activation into plasmin [26]. Autoregulation of PMN proteases corresponds to the interaction between the different classes of proteases. Cathepsin $G$ activates collagenase IV by cleaving its zymogen [54]. Collagenase IV has an inhibitory effect on serine protease inhibitors (or 
serpines), which promotes the activity of elastase, cathepsin $\mathrm{G}$ and plasmin.

\section{CONCLUSION}

The increase of the somatic cell count in milk causes a great change in most parameters related to the biochemical aspects. For quarter milk, no threshold in these variations seems to exist between 0 and 600000 cells. In tank milk, SCC below 200000 cells $/ \mathrm{mL}$ represents only minor risks of compositional change; however, in milk falling into the $400-600000$ cells $/ \mathrm{mL}$ category, a wide variability is observed. These modifications of milk composition have a variable impact on the quality of dairy products. An increase in SCC has a negative influence in cheese processing, in pasteurized milk grading and full cream milk powder grading during storage. The gelification of UHT milk seems influenced by SCC in interaction with the stage of lactation but the mechanisms are not completely elucidated. The impact on yoghurt processing has not been correctly studied.

The direct role of PMN in caseinolysis has been demonstrated but the mechanisms involved still need to be clarified. The role of PMN proteases and their activators/ inhibitors has recently been developed. Some variations of the proteolytic activities of PMN are measured in relation with the maturity or the activation of these cells. To study the impact of PMN, in their works, most authors use the LPS-model; it could yet be more accurate to study the relationship between SCC and milk quality in cases of milk from quarters infected with miscellaneous pathogens inducing subclinical mastitis because such milks are collected and used for human dairy foods.

\section{ACKNOWLEDGEMENTS}

This research was carried out within the Program of Arilait-Recherches on somatic cell count and milk composition.

\section{REFERENCES}

[1] Auldist M.J., Coats S., Sutherlands B.J., Mayes J.J., McDowell G.H., Rogers G.L., Effects of somatic cell count and stage of lactation on raw milk composition and the yield and quality of Cheddar cheese, J. Dairy Res. 63 (1996) 269-280.

[2] Auldist M.J., Coats S., Sutherlands B.J., Hardham J.F., McDowell G.H., Rogers G.L., Effects of somatic cell count and stage of lactation on the quality and storage life of ultra high temperature milk, J. Dairy Res. 63 (1996) 377-386.

[3] Auldist M.J., Coats S., Sutherlands B.J., Clarke P.T., McDowell G.H., Rogers G.L., Effects of somatic cell count and stage of lactation on the quality of full cream milk powder, Austr. Dairy Technol. 51 (1996) 94-98.

[4] Baldi A., Savoini G., Cheli F., Fantuz F., Senatore E., Bertocchi L., Politis I., Changes in plasmin-plasminogen-plasminogen activator system in milk from italian friesan herds, Int. Dairy J. 6 (1996) 1045-1053.

[5] Bank U., Ansorge S., More than destructive: neutrophil-derived serine proteases in cytokine bioactivity control, J. Leukocyte Biol. 69 (2001) 197-206.

[6] Barbano D.M., Practical guide for control of cheese yield, International Dairy Federation, Brussels, 2000, pp. 19-27.

[7] Barbano D.M., Rasmussen R.R., Lynch J.M., Influence of milk somatic cell count and milk age on cheese yield, J. Dairy Sci. 74 (1991) 369-388.

[8] Barrett F.M., Kelly A.L., McSweeney P.L.H., Fox P.F., Use of exogenous urokinase to accelerate proteolysis in cheddar cheese during ripening, Int. Dairy J. 9 (1999) 421427.

[9] Bastian E.D., Lo C.G., David K.M.N., Plasminogen activation in cheese milk: influence on Swiss cheese ripening, J. Dairy Sci. 80 (1997) 245-251.

[10] Bayles K.W., Wesson C.A., Liou L.E., Fox L.K., Bohach G.A., Trumble W.R., Intracellular Staphylococcus aureus escapes the endosome and induces apoptosis in epithelial cells, Infect. Immun. 66 (1998) 336-342.

[11] Bonnefoy A., Legrand C., Proteolysis of subendothelial adhesive glycoproteins (fibronectin, thrombospondin, and von Willerbrand factor) by plasmin, leukocyte cathepsin G, and elastase, Thromb. Res. 98 (2000) 323332.

[12] Borregaard N., Lollik E.K., Kjeldsen L., Sengeløv H., Bastholm L., Nielsen M.H., 
Bainton D.F., Human neutrophil granules and secretory vesicles, Eur. J. Haematol. 51 (1993) 187-198.

[13] Bruckmaier R.M., Schallibaum M., Blum J.W., Escherichia coli endotoxin induced mastitis in dairy cows: changes and importance of insulin-like growth factor and ocytocin, Milchwissenschaft 48 (1993) 374-378.

[14] Cigic B., Pain R.H., Location of the binding site for chloride ion activation of cathepsin C, Eur. J. Biochem. 264 (1999) 944-951.

[15] Conney S., Tiernan D., Joyce P., Kelly A.L., Effect of somatic cell count and poymorphonuclear leukocyte content of milk on composition and proteolysis during ripening of Swiss-type cheese, J. Dairy Res. 67 (2000) 301-307

[16] Considine T., Healyn A., Kelly A.L., McSweeney P.L.H., Proteolytic specificity of elastase on bovine $\beta-\mathrm{CN}$, Food Chem. 66 (1999) 463-470.

[17] Considine T., Healyn A., Kelly A.L., McSweeney P.L.H., Proteolytic specificity of elastase on bovine $\alpha_{\mathrm{s} 1}-\mathrm{CN}$, Food Chem. 69 (2000) 19-26.

[18] Considine T., Geary S., Kelly A.L., McSweeney P.L.H., Proteolytic specificity of cathepsin $G$ on bovine $\alpha_{\mathrm{s}}{ }^{-}$and $\beta$-caseins, Food Chem. 76 (2002) 59-67.

[19] Coulon J.B., Gasqui P., Barnouin J., Ollier A., Pradel P., Pomiès D., Effect of mastitis and related-germ on milk yield and composition during naturally-occuring udder infections in dairy cows, Anim. Res. 51 (2002) 383-393.

[20] Danø K., Andreasen J., Grondhal-Hansen J., Kristensen P., Nielsen L.S., Skriver L., Plasminogen activators, tissue degradation, and cancer, in: Klein G., Weinhouse S. (Eds.), Advances in cancer research, Vol. 44, Academic Press, inc., New York, London, 1985, pp. 140-239.

[21] Deluyker H.A., Milk yield fluctuations associated with mastitis, Flemish Vet. J. 62 (Suppl. 1) (1991) 207-214

[22] Eigel W.N., Effect of bovine plasmin on $\alpha_{\mathrm{s1}}{ }^{-}$, $\beta$ - and $\kappa$-caseins, J. Dairy Sci. 60 (1977) 1399-1407.

[23] Fox L.K., Heald C.W., Gwazdauskas F.C., Vinson W.E., Concentrations of glucocorticoids, bovine serum albumin, and somatic cells in milk, J. Dairy Sci. 64 (1981) 22582261.

[24] Gilles A.M., Keil B., Cleavage of $\beta-\mathrm{CN}$ by collagenases from Achromobacter iophagus and Clostridium histolyticum, FEBS Lett. 65 (1976) 369-372.
[25] Gilmore J.A., White J.H., Zavizion B., Politis I., Effects of stage of lactation and somatic cell count on plasminogen activator activity in bovine milk, J. Dairy Sci. (1995) 141-145.

[26] Grufferty M.B., Fox P.F., Milk alcaline proteinase, J. Dairy Res. 55 (1988) 609-630.

[27] Guidry A.J., Ost M., Mather I.H., Shainline W.E., Weinland B.T., Sequential response of milk leukocytes, albumin, immunoglobulins, monovalent ions, citrate and lactose in cows given infusions of Escherichia coli endotoxin into the mammary gland, Am. J. Vet. Res. 44 (1983) 2262-2267.

[28] Hamann J., Krömker V., Potential of specific milk composition variables for cow health management, Livest. Prod. Sci. 48 (1997) 201-208.

[29] Hurley M.J., Larsen L.B., Kelly A.L., McSweney P.L.H., The milk acid proteinase cathepsin D: a review, Int. Dairy. J. 10 (2000) 673-681.

[30] Hurley M.J., Larsen L.B., Kelly A.L., McSweney P.L.H., Cathepsin D activity in quarg, Int. Dairy. J. 10 (2000) 453-458.

[31] Jain N.C., Essential of veterinary hematology, Lea \& Febiger, Philadelphia, 1993, $417 \mathrm{p}$.

[32] Kelly A.L., Foley J., Proteolysis and storage stability of UHT milk as influenced by milk plasmin activity, plasmin/ $\beta$-lactoglobulin complexation, plasminogen activation and somatic cell count, Int. Dairy J. 7 (1997) 411420 .

[33] Kelly A.L., Tiernan D., O'Sullivan C., Joyce P., Correlation between bovine milk somatic cell count and polymorphonuclear leukocytes level for samples of bulk milk and milk from individual cows, J. Dairy Sci. 83 (2000) 300304.

[34] Klei L., Yun J., Sapru A., Lynch J., Barbano D., Sears P., Galton D., Effect of milk somatic cell count on cottage cheese and quality, J. Dairy Sci. 81 (1998) 1205-1213.

[35] Kohlmann K.L., Nielsen S.S., Ladisch M.R., Effects of a low concentration of added plasmin on ultra-high temperature processed milk, J. Dairy Sci. 74 (1991) 1151-1156.

[36] Lähteenmäki K., Kuusela P., Korhonen T.K., Bacterial plasminogen activators and receptors, FEMS Mirobiol. Rev. 25 (2001) 531552.

[37] Larsen L.B., Benfeldt C., Rasmussen L.K., Petersen T.E., Bovine milk procathepsin D and cathepsin D: coagulation and milk protein degradation, J. Dairy Res. 63 (1996) $119-130$ 
[38] Larsen L.B., Wium H., Benfeldt C., Heegaard C.W., Ardö Y., Qvist K.B., Petersen T.E., Bovine milk procathepsin D: presence and activity in heated milk and extracts of rennetfree UF-Feta cheese, Int. Dairy J. 10 (2000) 67-73.

[39] Le Bars D., Gripon J.C., Hydrolysis of $\alpha_{\mathrm{s} 1^{-}}$ casein by bovine plasmin, Lait 73 (1993) $337-344$

[40] Le Roux Y., Laurent F., Influence du dénombrement cellulaire sur les aptitudes technologiques de laits de tank, $6^{\mathrm{e}}$ Rencontre Recherche Ruminant, Paris 1, 2 décembre 1999, p. 316.

[41] Le Roux Y., Colin O., Laurent F., Proteolysis in samples of quarter milk with varying somatic cell counts. 1. Comparison of some indicators of endogenous proteolysis in milk, J. Dairy Sci. 78 (1995) 1289-1297.

[42] Leigh J.A., Lincoln R.A., Streptococcus uberis acquires plasmin activity following growth in the presence of bovine plasminogen through the action of its specific plasminogen activator, FEMS Microbiol. Lett. 154 (1997) 123-129.

[43] Ma Y., Ryan C., Barbano D.M., Galton D.M., Rudan M.A., Boor K.J., Effects of somatic cell count on quality and shelf-life of pasteurized fluid milk, J. Dairy Sci. 83 (2000) 264 274.

[44] Mattila T., Shandholm M., Antitrypsin and $\mathrm{N}$-acetyl- $\beta$-D-glucosaminidase as markers of mastitis in a herd of Ayshire cows, Am. J. Vet. Res. 46 (1985) 2453-2456.

[45] McSweeney P.L.H., Fox P.F., Proteolysis of bovine caseins by cathepsin D: preliminary observations and comparison with chymosin, Int. Dairy J. 5 (1995) 321-336.

[46] McSweeney P.L.H., Olson N.F., Fox P.F., Healy A., Hojrup P., Proteolytic specificity of plasmin on bovine $\alpha_{\mathrm{s}}$-casein, Food Biotechnol. 7 (1993) 143-158.

[47] Michelutti I., Variations des cellules somatiques et de la composition biochimique du lait en relation avec l'inflammation expérimentale de la glande mammaire, Thèse de doctorat, INPL-ENSAIA, Nancy, France, 1998, $152 \mathrm{p}$.

[48] Michelutti I., Le Roux Y., Rainard P., Poutrel B., Laurent F., Sequential changes in milk protein composition after experimental Escherichia coli mastitis, Lait 79 (1999) 535-549.

[49] Moir E., Booth N.A., Bennett B., Robbie L.A., Polymorphonuclear leukocytes mediate endogenous thrombus lysis via a u-PA- dependent mechanism, Br. J. Haematol. 113 (2001) 72-80.

[50] Moussaoui F., Michelutti I., Le Roux Y., Laurent F., Mechanisms involved in milk endogenous proteolysis induced by a lipopolysaccharide experimental mastitis, J. Dairy Sci. 85 (2002) 2562-2570.

[51] Munro G.L., Grieve P.A., Kitchen B.J., Effect of mastitis on milk yield, milk composition, processing properties and yield and quality of milk products, Austr. J. Dairy Techn. 39 (1984) 7-16.

[52] Nickerson S.C., Pankey J.W., Neutrophils migration through teat and tissues of bovine mammary quarters experimentally challenged with Staphylococcus aureus, J. Dairy Sci. 67 (1984) 826-834.

[53] Opdenakker G., Van den Steen P.E., Van Damme J., Gelatinase B: a tuner and amplifier of immune functions, Trends Immunol. 22 (2001) 571-579.

[54] Owen C.A., Campbell E.J., The cell biology of leukocyte-mediated proteolysis, J. Leukocyte Biol. 65 (1999) 137-150.

[55] Paape M., Guidry A.J., Effect of fat and casein in intracellular killing of Staphylococcus aureus by milk leukocytes, Proceeding of the Society for Experimental Biology and Medecine 155 (1977) 588-593.

[56] Politis I., Plasminogen activator system: implications for mammary cell growth and involution, J. Dairy Sci. 79 (1996) 10971107.

[57] Politis I., Zhao X., Mcbride B.W., Burton J.H., Turner J.D., Plasminogen activator production by bovine milk macrophages and blood monocytes, Am. J. Vet. Res. 52 (1991) 1208-1213.

[58] Politis I., Zavizion B., Barbano D.M., Gorewit R.C., Enzymatic assay for the combined determination of plasmin plus plasminogen in milk: revisited, J. Dairy Sci. 76 (1993) 1260 1267.

[59] Precetti A.S., Oria M.P., Nielsen S.S., Presence in bovin milk of two protease inhibitors of the plasmin system, J. Dairy Sci. 80 (1997) 1490-1496.

[60] Prin Mathieu C., Le Roux Y., Faure G.C., Laurent F., Béné M.C., Moussaoui F., Enzymatic activities of bovine peripheral blood leukocytes and milk polymorphonuclear neutrophils during intramammary inflammation caused by lipopolysaccharide, Clin. Diagn. Lab. Immunol. 9 (2002) 812-817. 
[61] Pyörälä S., Indicators of inflammation to evaluate the recovery from acute bovine mastitis, Res. Vet. Sci. 45 (1988) 166-169.

[62] Raulo S.M., Sorsa T., Tervahartiala T., Latvanen T., Pirilä E., Hirvonen J., Maisi P., Increase in milk metalloproteinase activity and vascular permeability in bovine endotoxininduced and naturally occuring Escherichia coli mastitis, Vet. Immunol. Immunopathol. 85 (2002) 137-145.

[63] Reboud-Ravaux M., Elastase inhibitors, J. Soc. Biol. 195 (2001) 143-150.

[64] Reinitz M., Paape M., Mather I.H., Effect of phagocytosed fat and casein on the intraphagosomal $\mathrm{pH}$ in bovine polymorphonuclear leukocytes, Proc. Soc. Exp. Biol. Med. 170 (1982) 281-286.

[65] Riollet C., Rainard P., Poutrel B., Cinétiques de recrutement cellulaire et de multiplication bactérienne après infection, Journées Nationales GTV-INRA, Nantes, France, 1999, Cellules somatiques du lait, 1999, pp. 23-28.

[66] Rogers S.A., Mitchell G.E., The relationship between somatic cell count, composition and manufacturing properties of bulk milk. Cheddar cheese and skim milk yoghurt, Aust. J. Dairy Technol. 49 (1994) 70-74.

[67] Russell M., Brooker B.E., Reiter B., Electron microscopic observations of the interaction of casein micelles and milk fat globules with bovine polymorphonuclear leucocytes during the phagocytosis of staphylococci in milk, J. Comp. Pathol. 87 (1977) 43-52.

[68] Schaar J., Funke H., Effect of subclinical mastitis on milk plasminogen and plasmin compared with that on sodium, antitrypsin and N-acetyl- $\beta$-D glucosaminidase, J. Dairy Res. 53 (1986) 515-528.

[69] Schepers A.J., Lam T.J., Schukken Y.H., Wilmink J.B., Hanekamp W.J., Estimation of variance components for somatic cells counts to determine thresholds for uninfected quarters, J. Dairy Sci. 80 (1997) 1833-1840.

[70] Shuster D.E., Harmon R.J., Jackson J.A., Hemken R.W., Endotoxin mastitis in cows milking four times daily, J. Dairy Sci. 74 (1991) 1527-1538.

[71] Silanikove N., Shamay A., Shinder D., Moran A., Stress down regulates milk yield in cows by plasmin induced beta-casein product that blocks $\mathrm{K}+$ channels on the apical membranes, Life Sci. 67 (2000) 2201-2212.

[72] Sordillo L.M., Nickerson S.C., Akers R.M., Pathology of Staphyloccus aureus mastitis during lactogenesis: relationships with bovine mammary structure and function, J. Dairy Sci. 72 (1989) 228-240.

[73] Sordillo L.M., Shafer-Weaver K., Derosa D., Symposium: bovine immunology. Immunobiology of the mammary gland, J. Dairy Sci. 80 (1997) 1851-1865.

[74] Takeuchi K.H., McGarry M.P., Swank R.T., Elastase and cathepsin G activities are present in immature bone marrow neutrophils and absent in late marrow and circulating neutrophils of beige (Chediak-Higashi) mice, J. Exp. Med. 166 (1987) 1362-1376.

[75] Targowski S.P., Role of immune factors in protection of mammary gland, J. Dairy Sci. 66 (1983) 1781-1789.

[76] Tokunaga H., Waguri S., Sato N., Ohsawa Y., Banya Y., Kominami E., Uchiyama Y., Lysosomal cysteine and aspartic proteinases and ubiquitin in rat and human urinary bladder epithelium, Arch. Histol. Cytol. 59 (1996) 249-260.

[77] Urech E., Puhan Z., Schällibaum M., Changes in milk protein fraction as affected by subclinical mastitis, J. Dairy Sci. 82 (1999) 2402-2411.

[78] Vandeputte-Van Messon G., Burvenich C. Roets E., Massart-Laeën A.M., Heyneman R., Kremer W.D.J., Brand A., Classification of newley calved cows into moderate and severe responders to experimentally induced Escherichia coli mastitis, J. Dairy Res. 60 (1993) 19-29.

[79] Verdi R., Barbano D.M., Properties of proteases from somatic cells and blood leukocytes, J. Dairy Sci. 74 (1991) 2077-2081.

[80] Yamagata K., Matsumura K., Inoue W., Shiraki T., Yasuda S., Sugiura H., Cao C., Wantanabe Y., Kobayashi S., Coexpression of microsomal-type prostaglandin E synthase with cyclooxygenase- 2 in brain endothelial cells of rats during endotoxin-induced fever, J. Neurosci. 21 (2001) 2669-2677.

[81] Zachos T., Politis I., Gorewit R.C., Barbano D.M., Effect of mastitis on plasminogen activator of milk somatic cells, J. Dairy Sci. 59 (1992) 461-467.

[82] Zavizion B., Heegard C.H., White J., Cheli F., Politis I., Synthesis of plasminogen activator inhibitor 1 by bovine mammary epithelial and myoepithelial cell lines, J. Dairy Res. 63 (1996) 451-458.

[83] Zavizion B., White J.H., Bramley A.J., Staphylococcus aureus stimulates urokinasetype plasminogen activator expression by bovine mammary cells, J. Infect. Dis. 176 (1997) 1637-1640 